\title{
EDUCAÇÃO PROFISSIONAL DA JUVENTUDE NA CRISE DO EMPREGO
}

\author{
Maria da Conceição da Silva Freitas
}

Curso: Doutorado em Sociologia

Data de defesa da tese: 3 de novembro de 2004

Orientadora: $\operatorname{Prof}^{\mathrm{a}} \operatorname{Dr}^{\mathrm{a}}$ Christiane Girard Ferreira Nunes

\section{Resumo}

Na sociedade contemporânea, a lógica societal do capitalismo tardio gerou uma nova sociabilidade que desemprega e precariza milhões de pessoas de todas as faixas etárias, e o desemprego tornouse um risco de desagregação social que afeta a juventude na faixa etária entre 15 e 24 anos. A crise da identidade mediada pelo trabalho também atinge a educação que, ao adotar as competências individuais e a noção de empregabilidade como possibilidade de inserção profissional perde a sua finalidade integradora. $\mathrm{O}$ setor produtivo demanda um perfil de formação integral: técnica e científica e desafia a dualidade estrutural - propedêutica e tecnicista/assistencialista do ensino médio. Essa questão preocupa a comunidade acadêmica ligada à pesquisa da educação e do trabalho.

A questão central da tese foi identificar como os atores sociais envolvidos com a escola técnica se movimentam diante do desemprego juvenil. $\mathrm{O}$ eixo conceitual da pesquisa estruturou-se na centralidade do trabalho como práxis social intersubjetiva (Lukács). $\mathrm{Na}$ teoria da ação comunicativa (Habermas), buscaram-se os elementos teórico-metodológicos para uma visibilidade de indicadores de participação. A interação entre a escola e o setor produtivo foi vista pela abordagem da formação integral, com fundamentos científico-tecnológicos e histórico-sociais (Ciavatta, Frigotto, Kuenzer) 
complementada pela heterogeneidade institucional (Gibbons) e intersubjetividade da ciência (Latour). A ambigüidade da noção de competências foi vista pelo pragmatismo que subordina o conhecimento à utilidade (Ramos, Ropé \& Tanguy) e pela contextualização (Lopes) como meio de implementação do discurso oficial na prática escolar. A noção de currículo como prática social (Popkewitz) e como regulação (Lopes \& Boaventura Santos) foi tomada para analisar como se estrutura a subjetividade por meio do currículo.

Conclui-se que a participação dos atores sociais é desigual. Uma das respostas dadas pela escola técnica ao desemprego juvenil é o desenvolvimento de uma ruptura conceitual da subjetividade na formação do aluno, via currículo, por meio da mudança do conceito de empregado para o de empreendedor. Os interesses dos atores sociais convergem para o aumento da oferta de estágios e emprego. Verificou-se que $89 \%$ dos alunos da amostra estão sem estágio. Surpreende o otimismo dos jovens em relação ao futuro do trabalho, pois $72 \%$ acreditam que poderão sustentar a família com o fruto do seu trabalho.

Palavras-chave: capitalismo tardio, desemprego, desagregação social, juventude, crise da identidade mediada pelo trabalho, educação profissional. 